DOI: https://doi.org/10.24127/ajpm.v10i4.4146

\title{
TINGKAT KECEMASAN MATEMATIS MAHASISWA DALAM MENGIKUTI PEMBELAJARAN ONLINE
}

\author{
Agung Putra Wijaya $^{1^{*}}$, Nurain Suryadinata ${ }^{2}$, Tia Agnesa ${ }^{3}$ \\ $1^{*}, 2,3$ Pendidikan Matematika FKIP Universitas Lampung \\ *Corresponding author. Jalan Prof. Dr. Soemantri Brodjonegoro No. 1 Gedung Meneng Bandar Lampung \\ E-mail: $\quad$ agung.wijaya@fkip.unila.ac.id ${ }^{1 *}$ \\ nurain.suryadinata@fkip.unila.ac.id ${ }^{2)}$ \\ tia.agnesa88@fkip.unila.ac.id ${ }^{3}$
}

Received 24 August 2021; Received in revised form 17 November 2021; Accepted 27 December 2021

\begin{abstract}
Abstrak
Penelitian deskriptif kualitatif ini dilakukan dengan tujuan untuk mendeskripsikan tingkat kecemasan matematis mahasiswa dalam mengikuti pembelajaran online dibandingkan dengan pembelajaran offline. Subjek penelitian ini diambil menggunakan secara purposive dengan melibatkan mahasiswa Program Studi Pendidikan Matematika FKIP Universitas Lampung semester genap pada tahun akademik 2019/2020. Data dikumpulkan melalui skala kecemasan matematis dan pedoman wawancara. Analisis data penelitian ini meliputi reduksi data, penyajian data, serta penarikan kesimpulan dan verifikasi. Berdasarkan hasil penelitian dan pembahasan, diperoleh simpulan bahwa (1) tingkat kecemasan matematis mahasiswa yang mengikuti pembelajaran online lebih tinggi dibandingkan pembelajaran offline dan (2) pada aspek kognitif dan afektif, tingkat kecemasan matematis mahasiswa yang mengikuti pembelajaran online lebih tinggi dibandingkan pembelajaran offline. Pada aspek fisiologis, tingkat kecemasan matematis mahasiswa yang mengikuti pembelajaran offline lebih tinggi dibandingkan pembelajaran online. Hasil penelitian menjadi masukan dalam merancang pembelajaran yang mampu meminimalisasi kecemasan matematis mahasiswa dalam mengikuti pembelajaran online.
\end{abstract}

Kata kunci: Afektif; fisiologis; kecemasan matematis; kognitif; offline; online.

\begin{abstract}
This qualitative descriptive study was conducted with the aim of describing students' mathematical anxiety levels in participating in online learning compared to offline learning. The subjects of this study were taken using purposive by involving students of the Mathematics Education, FKIP Universitas Lampung, even semesters in the academic year of 2019/2020. Data were collected through mathematical anxiety scale and interview guidelines. The data analysis of this research includes data reduction, data presentation, conclusion drawing and verification. Based on the results of research and discussion, it is concluded that (1) the level of mathematical anxiety of students who take online learning is higher than offline learning, (2) on the cognitive and affective aspects, the level of mathematical anxiety of students who take online learning is higher than offline learning. On the physiological aspect, the level of mathematical anxiety of students taking offline learning is higher than online learning. The results of this research become input in designing learning that is able to minimize students' mathematical anxiety in participating in online learning.
\end{abstract}

Keywords: Affective; cognitive; mathematical anxiety; offline; online; physiological.

This is an open access article under the Creative Commons Attribution 4.0 International License

\section{PENDAHULUAN}

Sejak Maret 2020, Indonesia menjadi salah satu negara di dunia yang ter- imbas pandemi Covid-19. Pandemi yang disebabkan oleh virus corona ini dapat berakibat fatal hingga merenggut 
nyawa manusia. Hal ini mendorong pemerintah Indonesia untuk mengeluarkan beberapa himbauan kepada publik, seperti himbauan work from home (WFH). Kaitannya dalam pendidikan, Menteri Pendidikan dan Kebudayaan mengeluarkan Surat Edaran Nomor 36962/MPK.A/HK/2020 agar seluruh kegiatan pembelajaran, baik di sekolah maupun perguruan tinggi menggunakan metode online sebagai upaya pencegahan terhadap perkembangan dan penyebaran Covid-19.

Dengan diterbitkannya surat edaran tersebut, seluruh mata kuliah pada semester genap tahun akademik 2019/ 2020 diajarkan secara online, termasuk mata kuliah berbasis matematika. Mata kuliah berbasis matematika yang dimaksud adalah mata kuliah yang memuat konsep matematika dalam bahan kajiannya. Matematika merupakan pengetahuan dengan objek kajian yang abstrak sehingga membutuhkan perlakuan pembelajaran dengan pendekatan saintifik untuk mengoptimalkan pemahaman konsep mahasiswa (Istikomah \& Jana, 2018; Yuselis, Ismail, \& Nery, 2015). Selama pembelajaran tatap muka di kelas sebelum pandemi Covid-19, setiap mata kuliah berbasis matematika menimbulkan kecemasan pada diri mahasiswa (Blazer, 2011; Kamarullah, 2017).

Banyak studi telah menunjukkan adanya variabel kecemasan yang kemudian disebut sebagai kecemasan matematis yang timbul pada diri mahasiswa dalam mengikuti pembelajaran tatap muka untuk mata kuliah berbasis matematika (Makur \& Prahmana, 2015; Widigda \& Setyaningrum, 2018; Dzulfikar, 2016; Rawa \& Yasa, 2018; Hartatik \& Fitriyah, 2017). Kecemasan matematis tersebut tidak hanya muncul pada aspek kognitif, tetapi juga pada aspek afektif dan fisiologis (Whyte \& Anthony, 2012).

Munculnya kecemasan matematis menyebabkan berkurangnya konsentrasi mahasiswa dalam belajar, tidak tenang (terkesan gugup), dan beberapa mahasiswa bahkan menunjukkan ciri fisiologis yang tidak seperti biasanya, seperti mual, berkeringat dingin, jantung berdebar, dan sakit kepala (Whyte \& Anthony, 2012). Jika mahasiswa memunculkan ciri-ciri tersebut selama belajar matematika, tentu saja proses penerimaan konsep menjadi kurang optimal (Utami \& Warmi, 2019). Alhasil, pemahaman konsep matematis menjadi lemah dan berdampak pada tidak optimalnya kemampuan mahasiswa dalam memecahkan masalah matematis (Ilmadi, 2018). Hal ini tentu berdampak buruk pada pencapaian prestasi belajar matematika mahasiswa.

Mencermati fenomena tersebut, tingkat kecemasan matematis menjadi variabel yang penting untuk diminimalisir karena berdampak sistemik terhadap pencapaian prestasi belajar matematika mahasiswa (Cooke, Cavanagh, Hurst, \& Sparrow, 2011; Aryani \& Hasyim, 2018; Ikhsan, 2019). Variabel ini harus menjadi perhatian setiap pendidik dalam mendesain pembelajaran yang efektif untuk diterapkan. Pembelajaran yang dilaksanakan harus mampu meminimalisir tingkat kecemasan matematis mahasiswa.

Perbedaan karakteristik pembelajaran tatap muka di kelas dan pembelajaran online memungkinkan akan memunculkan tingkat kecemasan yang berbeda pula. Ada kemungkinan bahwa mahasiswa mengalami kecemasan dalam mengikuti pembelajaran online atau justru sebaliknya, mahasiswa lebih menikmati pembelajaran online. Sampai saat ini, belum banyak penelitian yang mengkaji tingkat kecemasan matematis 
mahasiswa dalam pembelajaran online. Penelitian yang sudah banyak dilakukan berfokus pada tingkat kecemasan matematis siswa pada sekolah dasar hingga sekolah menengah. Oleh karena itu, penelitian ini penting untuk dilakukan guna mengkaji tingkat kecemasan matematis yang dialami oleh mahasiswa selama mengikuti pembelajaran online. Penelitian ini dilakukan dengan tujuan untuk mendeskripsikan tingkat kecemasan matematis mahasiswa dalam mengikuti pembelajaran online dibandingkan dengan pembelajaran offline.

Tingkat kecemasan matematis mahasiswa dalam mengikuti pembelajaran online ini dapat menjadi masukan bagi pendidik dalam merancang perlakuan pembelajaran inovatif yang mampu meminimalkan tingkat kecemasan matematis mahasiswa. Hal ini dapat berdampak pada peningkatan kualitas pembelajaran online. Alhasil, setiap mahasiswa akan memperoleh prestasi belajar yang optimal dalam mengikuti melalui pembelajaran online.

\section{METODE PENELITIAN}

Penelitian ini merupakan penelitian deskriptif kualitatif yang bertujuan untuk mendeskripsikan tingkat kecemasan matematis mahasiswa dalam mengikuti pembelajaran online. Penelitian ini dikatakan penelitian deskriptif karena analisis data yang dilakukan hanya sampai pada taraf deskripsi, yaitu menganalisis dan menyajikan fakta secara sistematik. Melalui pendekatan kualitatif, semua fakta, baik tulisan maupun lisan dari mahasiswa yang telah diamati dan dokumen terkait lainnya diuraikan apa adanya (tanpa manipulasi) kemudian dikaji dan disajikan seringkas mungkin untuk menjawab pertanyaan penelitian.
Penelitian ini dilaksanakan di Program Studi Pendidikan Matematika FKIP Unila semester genap pada tahun akademik 2019/2020. Pemilihan lokasi ini didasarkan pada pertimbangan bahwa (1) memudahkan untuk terciptanya kolaborasi antara peneliti dengan subjek penelitian dan (2) belum pernah diadakan penelitian yang mengukur tingkat kecemasan matematis dalam pembelajaran online pada mahasiswa Program Studi Pendidikan Matematika FKIP Universitas Lampung. Subjek penelitian ini diambil secara purposive.

Pada penelitian ini, data dikumpulkan secara langsung oleh peneliti, sehingga instrumen utamanya adalah peneliti sendiri. Sebagai suatu instrumen, peneliti harus mampu menyesuaikan dan berinteraksi secara langsung dengan fenomena-fenomena yang sedang diteliti.

Dalam pengumpulan data, instrumen utama didukung oleh instrumen bantu. Instrumen bantu dalam penelitian ini adalah skala kecemasan matematis dan pedoman wawancara. Skala kecemasan matematis digunakan untuk mengukur tingkat kecemasan matematis mahasiswa selama mengikuti pembelajaran. Instrumen ini berisi pernyataanpernyataan yang mengacu pada indikator-indikator dari tiga aspek kecemasan matematis, yakni kognitif, afektif, dan psikologis (Whyte \& Anthony, 2012). Indikator dari setiap aspek kecemasan matematis yang digunakan dalam penelitian ini disajikan pada Tabel 1.

Tabel 1. Faktor Kecemasan Matematis

\begin{tabular}{|c|c|}
\hline $\begin{array}{c}\text { Aspek } \\
\text { Kecemasan }\end{array}$ & Indikator \\
\hline Kognitif & $\begin{array}{l}\text { Kemampuan diri } \\
\text { Kepercayaan diri } \\
\text { Sulit konsentrasi } \\
\text { Takut gagal }\end{array}$ \\
\hline
\end{tabular}


DOI: https://doi.org/10.24127/ajpm.v10i4.4146

\begin{tabular}{cl}
\hline $\begin{array}{c}\text { Aspek } \\
\text { Kecemasan }\end{array}$ & \multicolumn{1}{c}{ Indikator } \\
\hline \multirow{2}{*}{ Afektif } & Gugup \\
& Kurang senang \\
& Gelisah \\
& Rasa mual \\
& Berkeringat dingin \\
Fisiologis & Jantung berdebar \\
& Sakit kepala \\
& Menangis \\
\hline
\end{tabular}

Sebelum skala kecemasan matematis ini digunakan, dilakukan validasi dengan mengacu pada lembar validasi yang memuat sejumlah pertanyaan yang berkaitan dengan kesesuaian butir pernyataan dengan indikator, kejelasan pernyataan, dan ketepatan bahasa yang digunakan dalam instrumen. Proses validasi instrumen ini dilakukan oleh validator. Hasil validasi menunjukkan bahwa skala kecemasan matematis ini layak digunakan untuk mengumpulkan data.

Pedoman wawancara disusun sebagai acuan dalam melakukan wawancara kepada subjek setelah mengisikan skala tingkat kecemasan matematis. Pedoman wawancara ini bersifat semi terstruktur dengan tujuan memudahkan untuk menemukan masalah-masalah secara terbuka, artinya subjek diajak mengemukakan pendapat dan keluhan (jika ada) selama mengikuti pembelajaran online. Sebelum digunakan, dilakukan validasi terhadap instrumen ini dengan mengacu pada lembar validasi. Proses validasi instrumen ini dilakukan oleh validator. Hasil validasi menunjukkan bahwa pedoman wawancara ini layak digunakan untuk mengumpulkan data.

Pengumpulan data menggunakan skala kecemasan matematis dilakukan secara online dengan menggunakan bantuan google form. Setelah data skala kecemasan matematis terkumpul, di- lakukan triangulasi metode. Triangulasi ini dilakukan dengan melaksanakan wawancara secara terjadwal. Mengingat masa pandemi covid-19, sebagian subjek terlibat wawancara secara online menggunakan bantuan zoom dan google meet. Sebagian subjek lainnya diwawancarai secara offline dengan menjalankan protokol kesehatan secara ketat. Data hasil triangulasi yang sama merupakan data subjek ke-i yang valid, sedangkan data yang berbeda direduksi atau dijadikan temuan lain dalam penelitian.

Setelah diperoleh data hasil penelitian, dilakukan analisis terhadap data tersebut. Adapun langkah-langkah analisis data penelitian ini meliputi reduksi data, penyajian data, serta penarikan kesimpulan dan verifikasi.

Tahap reduksi data dilakukan untuk menyusun rangkuman terhadap data yang diperoleh, baik dari hasil pengisian skala dan wawancara. Penyusunan rangkuman dilakukan dengan memilih informasi dengan berfokus pada hal-hal yang relevan dengan penelitian dan membuang data yang tidak perlu. Dengan demikian, data yang direduksi memberikan gambaran yang lebih spesifik tentang tingkat kecemasan matematis mahasiswa dalam pembelajaran online. Data yang telah direduksi, kemudian disajikan sebagai data tingkat kecemasan matematis mahasiswa dalam pembelajaran, baik offline dan online. Setelah data disajikan, dilakukan penarikan kesimpulan. Kesimpulan ini dibandingkan dengan bukti-bukti saat di lapangan. Apabila kesimpulan tersebut didukung oleh bukti-bukti yang kuat dalam arti konsisten dengan kondisi yang ditemukan di lapangan, maka kesimpulan tersebut kredibel. 
DOI: https://doi.org/10.24127/ajpm.v10i4.4146

\section{HASIL DAN PEMBAHASAN}

Berdasarkan hasil penelitian, diperoleh data tingkat kecemasan matematis pada pembelajaran offline dan online. Hasil penelitian menunjukkan bahwa tingkat kecemasan matematis mahasiswa yang mengikuti
pembelajaran
online lebih tinggi dibandingkan pembelajaran offline. Perbandingan tingkat kecemasan matematis mahasiswa pada pembelajaran offline dan online disaji- kan pada Gambar 1.

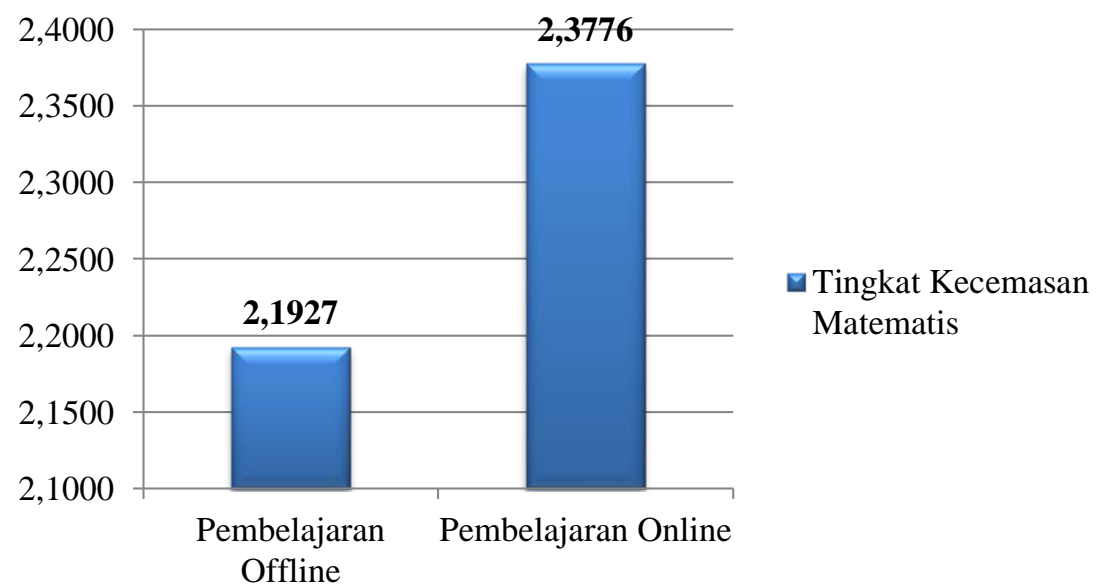

Gambar 1. Tingkat kecemasan matematis mahasiswa pada pembelajaran online dan offline

Data pada Gambar 1 menunjukkan bahwa tingkat kecemasan matematis mahasiswa yang mengikuti pembelajaran online lebih tinggi dibandingkan pembelajaran offline. Pembelajaran online hanya mempertemukan pendidik dan mahasiswa melalui dunia maya. Pertemuan melalui dunia maya tersebut kurang mampu memfasilitasi kebingungan yang dihadapi mahasiswa dalam memahami materi matematika selama pembelajaran berlangsung jika dibandingkan pertemuan yang dilakukan dalam dunia nyata. Karakteristik kajian matematika bersifat abstrak menuntut adanya bimbingan secara langsung dari para pendidik (Febrian \& Astuti, 2020). Kajian yang bersifat abstrak ini cenderung menimbulkan kebingungan dalam memahami kajian tersebut tanpa adanya bimbingan langsung dari pendidik.
Bimbingan langsung yang diberikan oleh pendidik ini lebih dirasakan melalui pembelajaran offline jika dibandingkan pembelajaran online. Hasil penelitian ini menunjukkan bahwa tanpa adanya bimbingan langsung dari pendidik dalam memahami materi matematika menciptakan kecemasan matematis pada diri mahasiswa, baik pada aspek kognitif, afektif, dan fisiologis.

Untuk mempertajam hasil penelitian, selain menyajikan data perbandingan tingkat kecemasan matematis pada pembelajaran offline dan online, hasil penelitian juga menyajikan perbandingan tingkat kecemasan matematis pada masing-masing aspek, yakni kognitif, afektif, dan fisiologis. Perbandingan tingkat kecemasan matematis pada pembelajaran offline dan online ditinjau pada masing-masing aspek disajikan pada Gambar 2. 
DOI: https://doi.org/10.24127/ajpm.v10i4.4146

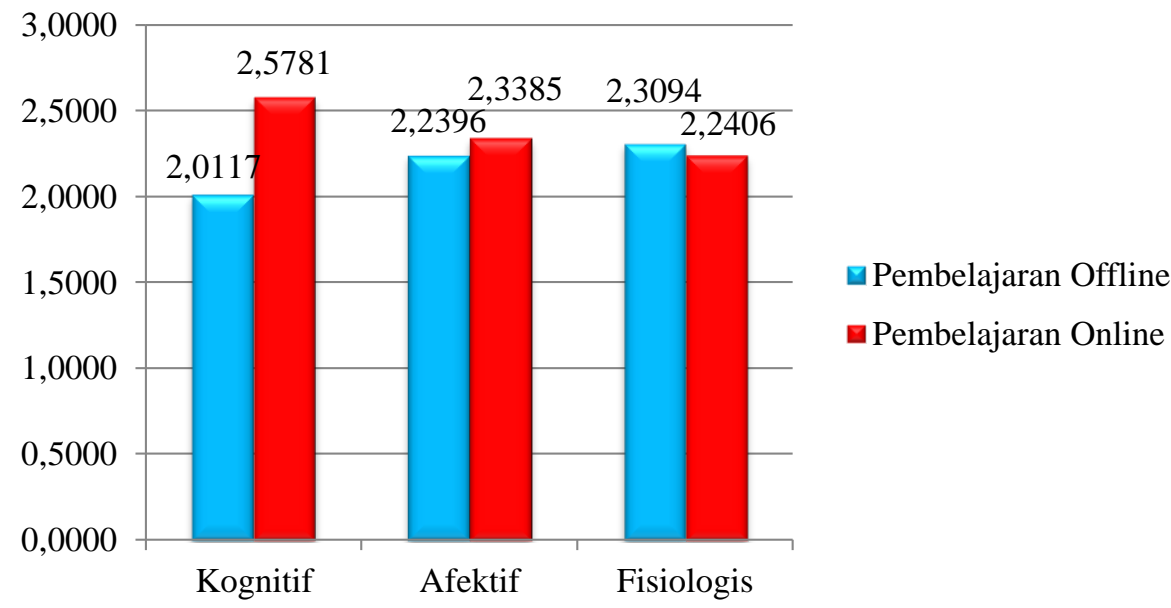

Gambar 2. Tingkat kecemasan matematis mahasiswa pada masing-masing aspek

Data pada Gambar 2 menunjukkan bahwa pada aspek kognitif dan afektif, tingkat kecemasan matematis mahasiswa yang mengikuti pembelajaran online lebih tinggi dibandingkan pembelajaran offline. Hal ini menunjukkan bahwa mahasiswa yang mengikuti pembelajaran online memiliki kecemasan terhadap kemampuan diri, kepercayaan diri, sulit konsentrasi, dan takut mengalami kegagalan dalam mengikuti pembelajaran matematika.

Kaitannya dengan aspek afektif, mahasiswa mengalami gugup, kurang nyaman, dan gelisah dalam mengikuti pembelajaran online. Rasa gugup, kurang nyaman, dan gelisah yang dialami oleh mahasiswa dalam mengikuti pembelajaran online ini justru lebih tinggi dibandingkan mahasiswa dalam mengikuti pembelajaran offline. Peserta didik merasa gugup dalam menyelesaikan masalah matematika tanpa bimbingan langsung dari pendidik (Harisuddin, 2021). Mahasiswa merasa kurang nyaman mengikuti pembelajaran yang sangat bergantung pada keberadaan jaringan dan arus listrik. Sebagai akibatnya, mahasiswa sangat gelisah dalam menghadapi pembelajaran dengan tingkat kecemasan yang lebih tinggi dibandingkan saat mengikuti pembelajaran offline.

Hasil wawancara menunjukkan bahwa mahasiswa tidak merasa puas dalam mengikuti pembelajaran online. Mahasiswa merasa tidak mampu memahami materi dengan baik. Menurut mahasiswa, penjelasan yang diberikan dalam pembelajaran online cenderung terbatas. Selain itu, meskipun diberikan kesempatan untuk bertanya, mahasiswa merasa tidak leluasa untuk menanyakan hal-hal yang belum dipahami. Mahasiswa juga mengatakan bahwa pada pembelajaran offline, mereka dapat lebih leluasa untuk bertanya, bahkan mengulang pertanyaan atau memberikan pertanyaan penegasan untuk memahami suatu materi. Akibatnya, mahasiswa bingung dalam memahami suatu materi dalam pembelajaran online.

Kebingungan yang mahasiswa rasakan tidak mampu terfasilitasi oleh pendidik melalui fasilitas online. Peserta didik merasa tidak memiliki ruang yang luas untuk menguasai materi melalui pembelajaran online (Basar, 2021). Hal ini mengakibatkan mahasiswa merasa tidak mampu menguasai materi dengan baik dan memiliki kepercayaan diri terhadap penguasaan konsep 
yang tidak maksimal. Selain itu, mahasiswa juga mengaku sulit fokus dalam mengikuti pembelajaran (Widodo \& Nursaptini, 2020). Hal ini karena banyaknya tugas yang dibebankan kepada mahasiswa dalam mengikuti pembelajaran online. Sulit menfokuskan diri terhadap pembelajaran juga dikarenakan kecemasan terhadap optimalisasi penguasaan konsep melalui pembelajaran online. Sebagai akibatnya, mahasiswa mengalami ketakutan terhadap keberhasilannya dalam mengikuti pembelajaran online. Mahasiswa juga mengakui bahwa masalah ini juga dialami dalam mengikuti pembelajaran matematika yang dilakukan secara offline. Hanya saja, tingkat masalahnya lebih rendah jika dibandingkan dengan pembelajaran online.

Berbeda halnya dengan aspek fisiologis, mahasiswa justru tidak mengalami kendala yang berarti dalam mengikuti pembelajaran online jika dibandingkan pembelajaran offline. Pada pembelajaran offline, mahasiswa justru mengalami gejala-gejala fisiologis yang membuat tidak nyaman dalam mengikuti pembelajaran. Gejala-gejala fisiologis tersebut seperti munculnya rasa mual, berkeringat dingin, jantung berdebar, muncul keluhan sakit kepala, dan keinginan untuk menangis dalam mengikuti pembelajaran offline. Gejala-gejala ini sebenarnya juga dialami oleh mahasiswa dalam mengikuti pembelajaran online, hanya saja tingkat kemunculannya lebih rendah jika dibandingkan dengan pembelajaran offline. Meskipun muncul kecemasan pada aspek kognitif dan afektif, mahasiswa mengaku dalam pembelajaran online dimana tidak berinteraksi secara langsung dengan dosen menyebabkan gejala-gejala kecemasan pada aspek fisiologis tidak muncul lebih tinggi dibandingkan pada pembelajaran offline yang secara langsung ber- interaksi dengan dosen. Interaksi antara dosen dan mahasiswa dimana dosen sering melakukan penunjukkan secara acak kepada mahasiswa untuk menyelesaikan suatu masalah di depan kelas secara signifikan memberikan kecemasan pada aspek fisiologis pada diri mahasiswa (Christianto, Kristiani, Franztius, Santoso, Winsen, \& Ardani, 2020). Hal menguntungkan bahwa pada pembelajaran online guru jarang melakukan penunjukkan secara acak kepada mahasiswa dalam menyelesaikan suatu masalah. Sebagai akibatnya, tingkat kecemasan matematis pada aspek fisiologis mahasiswa yang mengikuti pembelajaran online lebih rendah dibandingkan mahasiswa yang mengikuti pembelajaran offline.

Temuan penelitian ini menunjukkan bahwa tingkat kecemasan matematis mahasiswa yang mengikuti pembelajaran online lebih tinggi dibandingkan pembelajaran offline, khususnya pada aspek kognitif dan afektif. Temuan ini penting untuk mendapat perhatian dalam upaya meningkatkan kualitas pembelajaran dengan memperhatikan tingkat kecemasan matematis. Pembelajaran online yang dirancang hendaknya dapat meminimalisir tingkat kecemasan matematis, khususnya pada aspek kognitif dan afektif. Hal ini akan berdampak pada peningkatan prestasi belajar mahasiswa.

\section{KESIMPULAN DAN SARAN}

Berdasarkan hasil penelitian dan pembahasan, simpulan penelitian ini adalah (1) tingkat kecemasan matematis mahasiswa yang mengikuti pembelajaran online lebih tinggi dibandingkan pembelajaran offline dan (2) pada aspek kognitif dan afektif, tingkat kecemasan matematis mahasiswa yang mengikuti pembelajaran online lebih tinggi dibandingkan pembelajaran offline. Pada as- 
pek fisiologis, tingkat kecemasan matematis mahasiswa yang mengikuti pembelajaran offline lebih tinggi dibandingkan pembelajaran online.

Berdasarkan simpulan penelitian, saran yang dapat diberikan yakni dalam pembelajaran online, setiap pendidik hendaknya menggunakan media pembelajaran online yang sesuai guna meminimalkan tingkat kecemasan matematis kognitif dan afektif mahasiswa. Begitu pula pada pembelajaran offline, setiap pendidik hendaknya memperhatikan aspek fisiologis mahasiswa agar tidak menimbulkan kecemasan yang akan mengganggu proses pembelajaran.

\section{DAFTAR PUSTAKA}

Aryani, T. D., \& Hasyim, M. (2018). Pengaruh Kecemasan Matematis, Problem Stress Matematika, dan Self-Regulated Learning Terhadap Hasil Belajar Matematika. Aksioma Vol. 7 No. 2, 243 - 252.

Basar, A. M. (2021). Problematika Pembelajaran Jarak Jauh pada Masa Pandemi Covid-19. Edunesia: Jurnal Ilmiah Pendidikan Vol. 2 No. 1, 208 218.

Blazer, C. (2011). Strategies for Reducing Math Anxiety. Information Capsule Research Service Vo. 1102, 1 - 8.

Christianto, L. P., Kristiani, R., Franztius, D. N., Santoso, S. D., Winsen, \& Ardani, A. (2020). Kecemasan Mahasiswa di Masa Pandemi Covid-19. Jurnal Selaras, 67 - 82.

Cooke, A., Cavanagh, R., Hurst, C., \& Sparrow, L. (2011). Situational Effects of Mathematics Anxiety in Pre-Service Teacher Education. AARE Conference (pp. 1 - 14). Hobart, Tasmania: Australian
Association for Research in Education.

Dzulfikar, A. (2016). Kecemasan Matematika pada Mahasiswa Calon Guru Matematika. Jurnal Matematika dan Pendidikan Matematika, 34 - 44.

Febrian, F., \& Astuti, P. (2020). Pemahaman Objek Abstrak Matematika Guru Sekolah Menengah Atas di Kabupaten Bintan. Jurnal Anugrah, 13 - 18.

Harisuddin, M. I. (2021). Kemampuan Pemecahan Masalah Matematis dan Kemandirian Belajar Siswa dengan PJJ di Masa Covid-19. Teorema: Teori dan Riset Matematika Vol. 6 No. 1, 98 106.

Hartatik, S., \& Fitriyah, F. K. (2017). Identifikasi Kecemasan Matematika pada Mahasiswa Program Studi Pendidikan Guru Sekolah Dasar. Jurnal Bimbingan Konseling Indonesia Vol. 2 No. 2, $31-33$.

Ikhsan, M. (2019). Pengaruh Kecemasan Matematis Terhadap Hasil Belajar Matematika Siswa. de Fermat: Jurnal Pendidikan Matematika Vol. 2, No. 1, 1 - 6.

Ilmadi. (2018). Pengaruh Model Pembelajaran Berbasis PBI Terhadap Kemampuan Pemecahan Masalah dan Pemahaman Konsep Matematis Siswa Kelas X. Journal Saintika UNPAM Vol. 1 No. 1, 35 - 53.

Istikomah, D. A., \& Jana, P. (2018). Kemampuan Pemahaman Konsep Matematis Mahasiswa Melalui Pendekatan Pembelajaran Saintifik dalam Perkuliahan Aljabar Matrik. Seminar Nasional Pendidikan Matematika Etnomatnesia (pp. 927 - 932). Yogyakarta: Program Studi 
DOI: https://doi.org/10.24127/ajpm.v10i4.4146

Pendidikan Matematika FKIP Universitas Sarjanawiyata Tamansiswa.

Kamarullah. (2017). Pendidikan Matematika di Sekolah Kita. Al Khawarizmi: Jurnal Pendidikan dan Pembelajaran Matematika Vol. 1 No. 1, 21 - 32.

Makur, A. P., \& Prahmana, R. C. (2015). Penyebab Kecemasan Matematis Mahasiswa Calon Guru Asal Papua. Jurnal Elemen Vol. 1 No. 1, 1 - 12.

Rawa, N. R., \& Yasa, P. A. (2018). Kecemasan Matematika pada Mahasiswa Pandidikan Guru Sekolah Dasar. Journal of Education Technology Vol. 2 No. 2, $36-45$.

Utami, A. H., \& Warmi, A. (2019). Analisis Kesulitan Belajar Ditinjau dari Rasa Kecemasan Matematika. Seminar Nasional Matematika dan Pendidikan Matematika Sesiomadika (pp. 617 - 622). Karawang: Program Studi Pendidikan Matematika FKIP Universitas Singaperbangsa Karawang.

Whyte, J., \& Anthony, G. (2012). Math Anxiety: The Fear Factor in The Mathematics Classroom. New Zealand Journal of Teacher's Work Vol. 9 No. 1, 6 - 15.

Widigda, I. R., \& Setyaningrum, W. (2018). Kecemasan Mahasiswa Pendidikan Matematika Universitas Riau Kepulauan dalam Menghadapi Skripsi. Jurnal Pendidikan Matematika dan Sains Vol. VI No. 2, 190 199.

Widodo, A., \& Nursaptini. (2020). Problematika Pembelajaran Daring dalam Perspektif Mahasiswa. ELSE: Elementary
School Education Journal Vol. 4 No. 2, 100 - 115.

Yuselis, Ismail, F., \& Nery, R. S. (2015). Pengaruh Pendekatan Saintifik Terhadap Pemahaman Konsep Siswa pada Pembelajaran Matematika di Kelas VII MTs Patra Mandiri Palembang. Jurnal Pendidikan Matematika RAFA Vol. 1 No. 2, 258 - 287. 